\title{
USAGE OF LOW-ENERGY ELECTROMAGNETIC FIELDS OF MARGINAL HIGH-FREQUENCY RANGE FOR RECONSTRUCTION OF THE INJURED BY INFECTIOUS MICROORGANISMS ANIMAL SKIN
}

\author{
Taras Hutsol \\ State Agrarian and Engineering University in Podilya, Ukraine \\ E-mail: pro-gp@pdatu.edu.ua \\ Volodymyr Ivanyshyn \\ State Agrarian and Engineering University in Podilya, Ukraine \\ E-mail: volodymyrivanyshyn55@gmail.com \\ Serhii Yermakov \\ State Agrarian and Engineering University in Podilya, Ukraine \\ E-mail: ermkov@gmail.com \\ Serhii Komarnitskyi \\ State Agrarian and Engineering \\ University in Podilya, Ukraine \\ E-mail: sergiypetrov2207@gmail.com
}

Submission: $15 / 11 / 2018$

Revision: 08/02/2018 Accept: 27/02/2019

\section{ABSTRACT}

The paper is concerned with the mechanism of interaction between the electromagnetic field and the microorganisms. Currently the issue for usage of low-energy electromagnetic fields of marginal highfrequency range for reconstruction of the injured by infectious microorganisms animal skin is of great interest. The use of low-energy electromagnetic fields for restoring animal skin cover is significantly different from the existing physical and therapy procedures. The authors made the theoretical and the experimental research on updating and developing the low-energy electromagnetic technology and hardware of the electromagnetic field of high-frequency range to restore animal skin cover of infected wounds. The process of interaction between low-energy electromagnetic fields of highfrequency range in terms of infected animal skin cover is examined on the basis of the mathematic model. 
Particular attention was paid to theoretical aspect and cellular level analysis of the biotronic parameters of electromagnetic fields for the oppression of infectious microorganisms in wounds of animal skin cover and its effective reunion.

Keywords: low-energy electromagnetic field; high-frequency range; microorganism; animal skin cover

\section{INTRODUCTION}

At present, have been accumulated many facts, what indicating that, depending on the parameters of EMF (electromagnetic field), may change many the life activity aspects of living organisms, including farm animals (GOLANT, 1991; CHURMASOV; ZHUKOV; KUKUSHKINA; KALININA, 1996).

Recently has been discovered a new factor to regulate the physiological processes of EMF of URF (ultra-radio frequency) range, which affects the biorhythms of living organisms (ORLOV; KAZAKOV, 2000; BECKIJ; DEVYATKOV; LEBEDEVA, 2000). The use of low-energy EMF of URF range for the recovery of animal skin attacked by infectious microorganisms requires theoretical research on the distribution of EMF inside the bacterial cell and its influence on the membrane of cell cytoplasm (LACY-HULBERT; METCALFE; HESKETH, 1998; BORYSEVYCH, 1992; HUTSOL, 2017; SIMKÓ; MATTSSON, 2004).

The main molecular components of biological membranes are proteins and lipids that make more than a half of dry cell mass. The basic membrane-forming lipids are the unions with the perfect combination of hydrophobic and the hydrophilous properties. They are poorly soluble in water monomeric form, and the tendency of their polar heads to maximize contact with water gives them the unique ability to create multiform resistant structures in terms of aggregation of these molecules.

An important feature of almost all the models is the fact that the surface of cell membranes is considered as the most probable place for such actions. Despite some progress in the research on the action of low-energy EMF on biological objects, most of the primary molecular mechanisms of these actions are almost not identified. 
In our opinion, this is explained by the fact that, on the one hand, physical approach to the living matter is insufficient, and, on the other hand, the successful search of an appropriate simple model of processes in biological structures is difficult and sometimes impossible.

Knowledge of primary, physically based mechanisms of influence of low energy EMF on microorganisms, as well as the mechanism of the relationship between molecular and system levels will explain the phase direction of bioelectronic and magnetic effects and give the possibility to predict their occurrence that is especially important for the oppression of infectious microorganisms in the wounds of animals.

\section{DATA AND RESEARCH METHODOLOGY}

Taking into account the fact that the experimental investigation of the internal field transmission is almost impossible, the only way out is solving this problem with the help of theoretical methods.

In mathematical modeling of the process of scattering EMF at a biological object, suppose that it has a structure of plane parallel layers. Considering a skin cover, we will consider the first layer to be a wool cover, the second one is skin and the third layer is muscles.

To solve the problem is used the equation of Maxwell in differential form, with the help of which are determined the parameters of influence EMF and evaluated using graphic interpretations.

\section{RESULTS AND DISCUSSIONS}

\subsection{Determination of internal EMF in single-layer objects in terms of external EMF influence}

Analysis of experimental research on the EMF of SHF range influence on biological objects of different nature shows that the following measures cause the significant changes in the cellular level even in terms of marginal power levels (10 microwatts/cm2). It should be noted that the degree of this action is determined not only by the value of EMF power but also by its frequency and modulation characteristics. 
The influence of EMF of SHF on different microorganisms and insects is well explored from the experimental point of view, but the mechanism of this action itself is not examined, both at the organism and at the cellular levels. The study of the mechanism of the interaction between EMF and microorganisms is impossible without the information about the transmission of these fields inside the cells of microorganisms.

To get the original expression, that allows solving the given problem, at first, let's consider the scattering of a plane electromagnetic wave at a biological object, that has the structure of plane-parallel layers. So, if we deal with a skin cover, we will consider the first layer to be a wool cover, the second one is skin and the third layer is muscles.

Let us suppose that the irradiating area is homogeneous in planes, which are parallel to the surface of the radiation. It will allow us to explore the distribution of EMF only in the direction that is perpendicular to the skin surface. In addition, let's imagine that the EMF falls also perpendicular to the skin surface and the irradiating area has linear dimensions and is much longer than the wavelength (about $8 \mathrm{~mm}$ ) it will let not to take into account the edge effects.

Let us imagine that the wool cover is characterized by dielectric and magnetic penetration $\varepsilon_{1}$ and $\mu_{1}$, skin $\varepsilon_{2}$ and $\mu_{2}$, muscles $\varepsilon_{3}$ and $\mu_{3}$. The outer space in relation to the skin is considered to be simple. It is characterized by a permanent electric and magnetic penetration $\varepsilon_{0}$ and $\mu_{0}$.

In the case we consider the environment is air, then ${ }^{\varepsilon_{0}}=\frac{1}{36 \pi} \cdot 10^{-9} \mathrm{~F} / \mathrm{m}$.

It should be noted that the biological objects are not the magnetic materials, so for further research, we will use $\mu_{0}=\mu_{1}=\mu_{2}=\mu_{3}=4 \pi \cdot 10^{-7} \mathrm{TR} / \mathrm{m}$.

Both dielectric penetration and density of three-layered skin surface of agricultural animals (cattle) have the following characteristics:

- for wool $\rho_{1}=1,28-1,33 \mathrm{~kg} / \mathrm{m} 3$;

- for skin cover $\rho_{2}=928 \mathrm{~kg} / \mathrm{m} 3$;

- for tissue muscle $\rho_{3}=1033-1048 \mathrm{~kg} / \mathrm{m} 3$. 
To solve the problem, the equation of Maxwell in differential form is used (ILYIN; POZNIAK, 1978; KALYNYCHENKO; HORDYICHUK, 2006; SEREDA, 2007; RUBYN, 1987).

Let's suppose that a flat electromagnetic wave falls on the surface of the animal skin, which has a structure of flat parallel and isotopes homogeneous layers of wool cover, skin and muscle $\mathrm{d} 1, \mathrm{~d} 2, d_{3}$ thick, and propagates in the direction opposite to the surface of the skin, which we combine with $O X$ and $O Y$ axes of rectangular coordinate system $(x, y, z)$ (fig. 1).

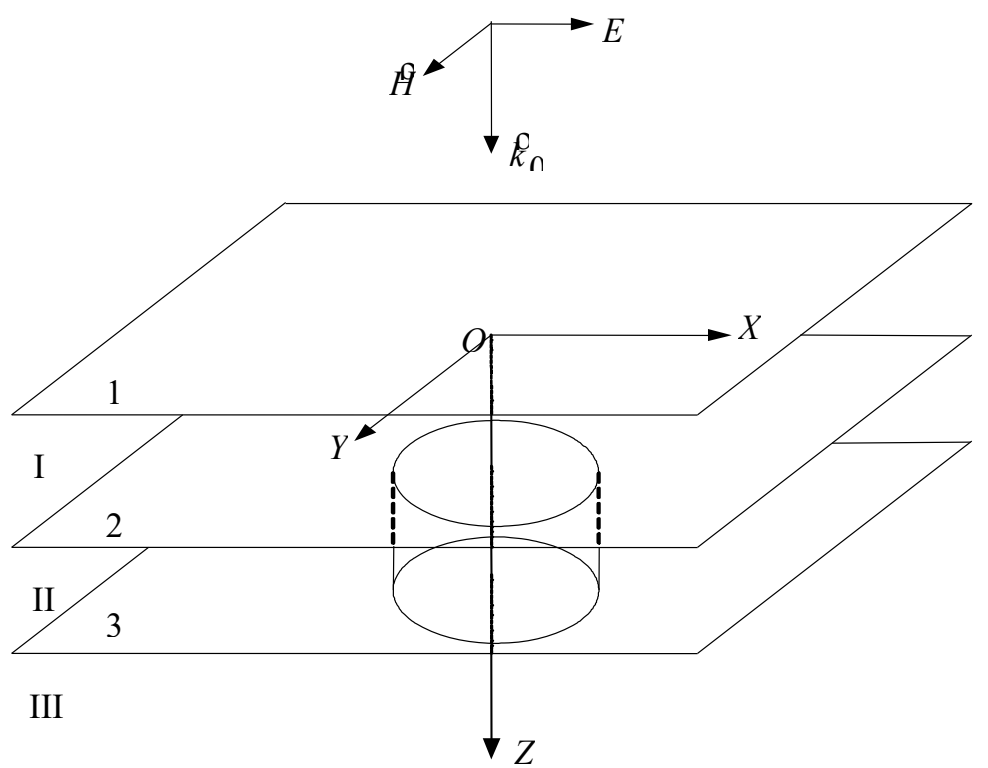

Graph 1: A model of a layered environment of particular animal skin cover: $1-$ the limit of wool cover; 2 - skin limits; 3 - muscle limits; I - the layer of wool cover; II the layer of the skin; III - the layer of muscles

To make everything clear, we consider $E$ vector to be parallel to the $O X$ axis and $\hat{H}$ vector to be parallel to $O Y$ an axis.

On the edge of each layer the mentioned fields must satisfy the boundary conditions, i.e., the tangential components of the vectors of the electric and the magnetic fields have to be continuous. The following conditions cause the system of equations. 
DOI: 10.14807/ijmp.v10i7.907

$$
\left\{\begin{array}{c}
\left.E_{x}^{0+}\right|_{z=0}+\left.E_{x}^{0-}\right|_{z=o}=\left.E_{x}^{1+}\right|_{z=0}+\left.E_{x}^{1-}\right|_{z=0} \\
\left.H_{y}^{0+}\right|_{z=o}+\left.H_{y}^{0-}\right|_{z=0}=\left.H_{y}^{1+}\right|_{z=0}+\left.H_{y}^{1-}\right|_{z=0} \\
\left.E_{x}^{1+}\right|_{z=d_{1}}+\left.E_{x}^{1-}\right|_{z=d_{1}}=\left.E_{x}^{2+}\right|_{z=d_{1}}+\left.E_{x}^{2-}\right|_{z=d_{1}} \\
\left.H_{y}^{1+}\right|_{z=d_{1}}+\left.H_{y}^{1-}\right|_{z=d_{1}}=\left.H_{y}^{2+}\right|_{z=d_{1}}+\left.H_{y}^{2-}\right|_{z=d_{1}} \\
\left.E_{x}^{2+}\right|_{z=d_{1}+d_{2}}+\left.E_{x}^{2-}\right|_{z=d_{1}+d_{2}}=\left.E_{x}^{3+}\right|_{z=d_{1}+d_{2}} \\
\left.H_{y}^{2+}\right|_{z=d_{1}+d_{2}}+\left.H_{y}^{2-}\right|_{z=d_{1}+d_{2}}=\left.H_{y}^{3+}\right|_{z=d_{1}+d_{2}}
\end{array}\right.
$$

Superscript 0 in the system (1) shows the EMF component is considered in the environment; superscript 1 refers to the first layer; superscript 2 refers to the second layer; superscript 3 refers the third layer.

Besides, the plus sign refers to a field that is propagated in the positive $O Z$ direction; the minus sign refers to a field that is propagated in a negative direction of the $O Z$ axis.

Let us take into account that:

$$
\begin{aligned}
& E_{x}^{0+}=E_{0} e^{-j k_{0} z} ; E_{x}^{0-}=a_{1} e^{-j k_{0} z} ; H_{y}^{0+}=E_{0} W_{0} e^{-j k_{0} z} ; \\
& H_{y}^{0-}=a_{1}^{-} W_{0} e^{j k_{0} z} ; E_{x}^{1+}=a_{1}^{+} e^{-j k_{1} z} ; E_{x}^{1-}=a_{2}^{-} e^{j k_{1} z} ; H_{y}^{1+}=a_{1}^{+} W_{1} e^{-j k_{1} z} ; \\
& H_{y}^{1-}=a_{2}^{-} W_{1} e^{j k_{1} z} ; E_{x}^{2+}=a_{2}^{+} e^{-j k_{2} z} ; E_{x}^{2-}=a_{3}^{-} e^{j k_{2} z} ; H_{y}^{2+}=a_{2}^{+} W_{2} e^{-j k_{2} z} ; \\
& H_{y}^{2-}=a_{3}^{-} W_{2} e^{j k_{2} z} ; E_{x}^{3+}=a_{3}^{+} e^{-j k_{3} z} ; H_{y}^{3+}=a_{3}^{+} W_{3} e^{-j k_{3} z},
\end{aligned}
$$

$E_{0}$ - tension amplitude of electrical component, falling from the EMF;

$a_{1}^{-}, a_{1}^{+}, a_{2}^{-}, a_{2}^{+}, a_{3}^{-}, a_{3}^{+}-$unknown amplitude of the reflected $(-)$and those that passed $(+)$ on each of the three borders of layers of EMF components;

$W_{0}=\sqrt{\frac{\mu_{0}}{\varepsilon_{0}}}, W_{1}=\sqrt{\frac{\mu_{0}}{\varepsilon_{1}}}, W_{2}=\sqrt{\frac{\mu_{0}}{\varepsilon_{2}}}, W_{3}=\sqrt{\frac{\mu_{0}}{\varepsilon_{3}}}-$ wave resistance of the air and each of the three layers of the skin;

$k_{1}=\omega \sqrt{\varepsilon_{1} \mu_{0}}, \quad k_{2}=\omega \sqrt{\varepsilon_{2} \mu}, \quad k_{3}=\omega \sqrt{\varepsilon_{3} \mu_{0}}$ - wave numbers in the environment and in each of the layers; $\omega-\quad$ is the frequency of the incident field.

$j=\sqrt{-1}$. In the examples, the $e^{j \omega t}$ element-free multiplier for the amplitude is omitted. 
Using the mentioned marks, the system (2) can be rewritten in the following way:

$$
\left\{\begin{array}{c}
E_{0}+a_{1}^{-}=a_{1}^{+}+a_{2}^{-} \\
\frac{1}{W_{0}}\left(E_{0}-a_{1}^{-}\right)=\frac{1}{W_{1}}\left(a_{1}^{+}-a_{2}^{-}\right) \\
a_{1}^{+} e^{-j k_{1} d_{1}}+a_{2}^{-} e^{j k_{1} d_{1}}=a_{2}^{+} e^{-j k_{2} d_{1}}+a_{3}^{-} e^{j k_{2} d_{1}} \\
\frac{1}{W_{1}}\left(a_{1}^{+} e^{-j k_{1} d_{1}}-a_{2}^{-} e^{j k_{1} d_{1}}\right)=\frac{1}{W_{2}}\left(a_{2}^{+} e^{-j k_{2} d_{1}}-a_{3}^{-} e^{j k_{2} d_{1}}\right) \\
a_{2}^{+} e^{-j k_{2}\left(d_{1}+d_{2}\right)}+a_{3}^{-} e^{j k_{2}\left(d_{1}+d_{2}\right)}=a_{3}^{+} e^{-j k_{3}\left(d_{1}+d_{2}\right)} \\
\frac{1}{W_{2}}\left(a_{2}^{+} e^{-j k_{2}\left(d_{1}+d_{2}\right)}-a_{3}^{-} e^{j k_{2}\left(d_{1}+d_{2}\right)}\right)=\frac{a_{3}^{+}}{W_{3}} e^{-j k_{3}\left(d_{1}+d_{2}\right)}
\end{array}\right.
$$

So, not the uniform system of linear algebraic equations with six unknown coefficients we have got, which characterize the passage and reflection coefficients on each of the three boundaries between layers.

Since the determinant of the system composed of the coefficients in the terms of the unknown is not equal to zero, the system is an invertible and has only one solution, which can be made with the help of Cramer's method (KALYNYCHENKO; HORDYICHUK, 2008; KRASNOV; KYSYLOV; MAKARENKO, 1976).

In the process of solving the system of linear algebraic equations (2), we found the following coefficients $a_{1}^{-}, a_{1}^{+}, a_{2}^{-}, a_{2}^{+}, a_{3}^{-}, a_{3}^{+}$, which allow us to find the magnitude of EMF amplitudes at each of the layers of the animal skin cover. Obviously, the magnitude of the electric field component in the wool cover may be defined by the following mathematical expression:

$$
E_{x}^{1}=a_{1}^{+} e^{-j k_{1} z}+a_{2}^{-} e^{j k_{1} z}, z \in\left(0, d_{1}\right)
$$

In skin cover:

$$
E_{x}^{2}=a_{2}^{+} e^{-j k_{2} z}+a_{3}^{-} e^{j k_{2} z}, z \in\left(d_{1}, d_{1}+d_{2}\right)
$$

In muscular tissue:

$$
\left.E_{x}^{3}=a_{3}^{+} e^{-j k_{3} z}, z\right\rangle d_{1}+d_{2}
$$

3.2. The distribution of the electromagnetic fields in wounds of animal skin cover 
The decrease of the electric field component amplitude over its thickness takes place in the epidermis. This will cause the emergence of the field gradient along the cylinder axis, which corresponds to the diffraction of the wave that has $E$ polarization.

In the case of $E$-polarization it is convenient to take the incident fields, scattered and those that passed inside the cylinder waves into cylinder functions (CHERENKOV, 2015):

$$
\begin{aligned}
& \left\{\begin{array}{l}
E_{z}^{\text {fall }}=E_{2} \sum_{n=-\infty}^{\infty} i^{n} j_{n}\left(k_{2} r\right) e^{i o t} \\
E_{z}^{d i s p}=\sum_{n=-\infty}^{\infty} a_{n}^{d i s p} H_{n}^{(2)}\left(k_{2} r\right) e^{i \omega t} ; \\
E_{z}=\sum_{n=-\infty}^{\infty} a_{n} j_{n}(k r) e^{i \omega t}
\end{array}\right. \\
& \left\{\begin{array}{l}
H_{z}^{\text {fall }}=0 \\
H_{z}^{d i s p}=\sum_{n=-\infty}^{\infty} b_{n}^{d i s p} H_{n}^{(2)}\left(k_{2} r\right) e^{i \omega t}, \\
H_{z}=\sum_{n=-\infty}^{\infty} b_{n} j_{n}(k r) e^{i \omega t}
\end{array}\right.
\end{aligned}
$$

where falling and scattered waves are marked by the "fall" and "disp" indices; the internal fields of the cylinder do not have indexes;

$$
\begin{aligned}
& k_{2}=\omega \sqrt{\varepsilon_{2} \mu_{0}} ; \\
& k=\omega \sqrt{\varepsilon \mu_{0}} ;
\end{aligned}
$$

$a_{n}^{\text {disp }}, \quad b_{n}^{\text {disp }}, \quad a_{n}, \quad b_{n}$ - unknown coefficients;

$J_{n}(k r)$ - Bessel function -of the 1st kind;

$H_{n}^{(2)}-$ Hankel function of the 2nd kind;

$E_{2}$ - the amplitude of the electric component of the field in the second layer of the skin cover. 
With the help of Maxwell equations, the rest components of an incident, scattered and those waves that passed inside the cylinder are determined. Thus, the amplitudes of the internal fields of the cylinder are described with the help of the following expressions:

$$
\left\{\begin{array}{l}
E_{z}=\sum_{n=-\infty}^{\infty} a_{n} j_{n}(k r) \\
H_{\rho}=-\sum_{n=-\infty}^{\infty} \frac{n a_{n} j_{n}(k r)}{\omega \mu r} . \\
H_{\varphi}=-\sum_{n=-\infty}^{\infty} \frac{i k a_{n} j_{n}^{\prime}(k r)}{\omega \mu}
\end{array} .\right.
$$

However, to determine the energy characteristics of the biological object of the fields that got inside, as well as for the definition of the main electromagnetic characteristics of the interaction between the field and the object there is no need to take a large number of harmonics in expressions (8). It is enough to take the zero harp. With the help of $n_{n=0}$, we get the formula that is suitable for practical calculations of internal fields in bio-objects of cylindrical shape:

$$
\left\{\begin{array}{l}
E_{z}=a_{0} j_{0}(k r) \\
H_{\varphi}=i \frac{a_{0} k^{2} j_{1}(k r)}{\omega \mu},
\end{array}\right.
$$

Where

$$
\begin{aligned}
& a_{0}=\frac{J_{0}\left(k_{2} a\right)+a_{0}^{D I S P} H_{0}^{(2)}\left(k_{2} a\right)}{J_{0}(k a)} E_{2} ; \\
& a_{0}^{D I S P}=\frac{J_{0}\left(k_{2} a\right)}{H_{0}^{(2)}\left(k_{2} a\right)}-2 i \frac{\left.\frac{J_{1}(k a)}{a J_{0}(k a)}-\frac{H_{1}^{(2)}\left(k_{2} a\right)}{a H_{0}^{(2)}\left(k_{2} a\right)}\right]}{\pi k_{1}^{2} a^{2}\left(H_{0}^{(2)}\left(k_{2} a\right)\right)^{2} D} ; \\
& D=\left[\frac{J_{1}(k a)}{a J_{0}(k a)}-\frac{H_{1}^{(2)}\left(k_{2} a\right)}{a H_{0}^{(2)}\left(k_{2} a\right)}\right]\left[\frac{k^{2} J_{1}(k a)}{k_{2}^{2} a J_{0}(k a)}-\frac{H_{1}^{(2)}\left(k_{2} a\right)}{a H_{0}^{(2)}\left(k_{2} a\right)}\right] .
\end{aligned}
$$


The expressions we obtained describe the distribution of EMF within the biological objects of cylinder form when their characteristics are not changed in volume.

\subsection{Multiplex calculation of EMF inside both, the healthy animal skin cover and infected wounds}

On the basis of expressions (3) - (5) the calculations on the distribution of the electric field component inside the animal skin cover were worked out (graph 1). The electrophysical characteristics and thickness of layers are taken from (LEVYTSKA; MUSHYNSKYI; HUTSOL, 2017), the amplitude of the electric component of the incident field is taken equal to one to make re-calculation to specific values of a field easier. Calculations are performed for $35 \mathrm{GHz}$ medium frequency, for $30-40 \mathrm{GHz}$ frequency band.

The graphic (graph 2) shows the depth of EMF penetration inside animal skin cover, which varies from 0 to 1 on the $X$-axis. The module of the complex amplitude of the EMF electric component is given on the $\mathrm{Y}$-axis.

To make the values of dielectric permeability of tissue layers that make a skin cover specific, the graph has the least value inside the skin layer, moreover, it is located near the border of muscle layer.

The computations are performed for animal tissue and their electrophysical parameters have the following value:

Wool cover $\varepsilon_{\mu p}=4,63-5,36$; skin cover $\varepsilon_{\kappa p}=5,9-4,9 ;$ muscles $\varepsilon_{M}=46,5$ $-47,3$.

The computations of electromagnetic fields inside the infected wounds of the animal skin were performed on the basis of shown results. The change of the electrical characteristics at the cylinder ends is automatically taken into account by boundary conditions at the plane-parallel layers.

First of all, the dependence of the electric field amplitude on the cylinder axis of the infected animal skin on the frequency of EMF incident was examined (graph 3 ). The calculations were made for the middle layer of animal skin. The frequency 
changed from 30 to $40 \mathrm{GHz}$, and the dielectric parameters of the epidermis and cocci colonies were equal:

$\varepsilon^{\prime}=5,4, \varepsilon^{\prime \prime}=0,1 ; \varepsilon^{\prime}=10 ; \varepsilon^{\prime \prime}=1,2$

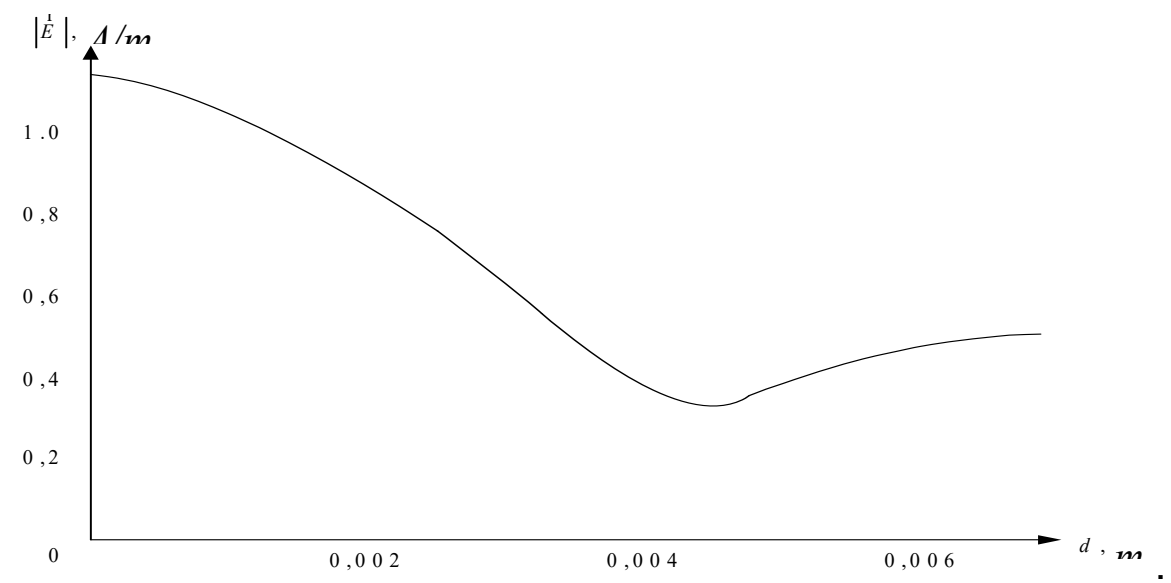

Graph 2: Module distribution by the electrical component of the EMF inside the healthy animal skin: wool cover $0-0.003 \mathrm{~m}$; skin $0.003-0.005 \mathrm{~m}$; muscles $0.005 \mathrm{~m}$ and deeper

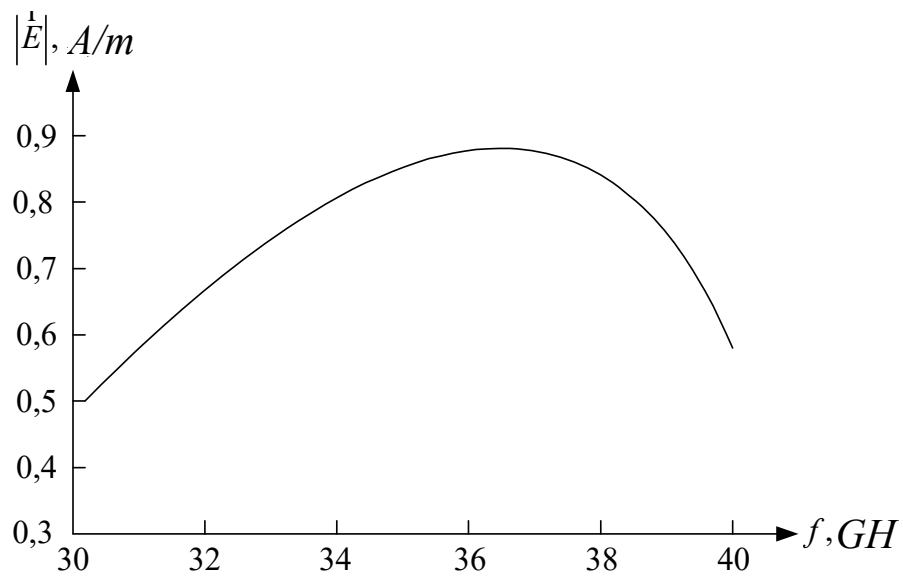

Graph 3: The dependence of the electric field amplitude inside the cylinder of the infected animal skin on the frequency of incident EMF

The following chart shows that the increasing frequency from $30 \mathrm{GHz}$ to 36 $\mathrm{GHz}$ causes the monotonous increasing of electric field amplitude, reaching its maximum at $36 \mathrm{GHz}$.

Further increasing of the frequency causes the internal field amplitude loss up to $40 \mathrm{GHz}$. The obtained results prove the EMF optimal frequency to oppress the pathogenic skin microorganisms is in the $35-37 \mathrm{GHz}$ frequency range.

Graph 4 represented the dependence of electric component amplitudes of EMF inside the wound of the animal skin cover. The change in EMF depending on 
the distance from the axis of the cylinder area of the pathogenic cocci colony is shown.

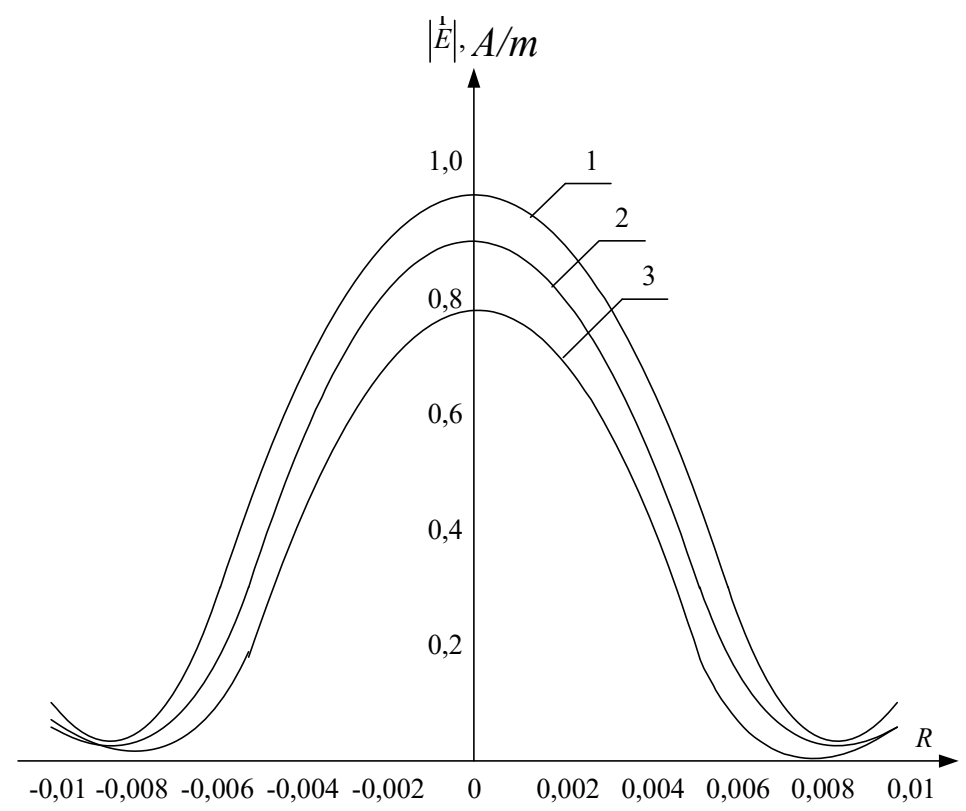

Graph 4: The dependence of the electric component amplitude of the EMF in the individual wound of animal skin cover from the pathogenic colony of cocci for 36.0

$\mathrm{GHz}$ frequency

The graphic shows that on the cylinder axis where the infected skin area is, the amplitude is maximum and exceeds the field amplitude of the healthy skin.

\subsection{Membrane destruction of the pathogenic cocci cells in terms of low- energy EMF of SHF range action}

The deflection of the membrane from the balance you can associate with the occurrence of defects in the structure of membranes due to local compression in longitudinal or transverse direction. Accidental reduction in the thickness of the membrane is of local character that should be considered as the initial phase of forming local deepening.

The most recognized is the mechanism of destruction of the membrane, caused by defects in the type of transverse pores. Let us suggest that in this case the formation of the defect is accompanied by changing the lipid molecules, located near the border of the defect with the formation of the so-called inverted pores (LEVYTSKA; MUSHYNSKYI; HUTSOL, 2017). The value of the critical radius ${ }_{\left(r_{0}\right)}$ of the defect in the cell membrane, where the transverse pore is not closed, is demonstrated with the help of the following correlation: 


$$
r_{0}=\delta /\left(\delta+C \frac{\varphi_{\text {lim }}^{2}}{2}\right)^{\prime}
$$

where $z-$ is a linear pull of the length unit of the perimeter of the defect;

$\delta$ - the superficial tension of the membrane;

$C=C_{1}\left(\frac{\varepsilon_{B}}{\varepsilon_{m}}\right)$, where $C_{1}-$ the volume of the unit area of the membrane, $\varepsilon_{B}-$ the dielectric constant of water, $\varepsilon_{m}$ - the dielectric constant of the membrane, $\varphi_{\lim }-$ the critical capacity, the excess of which leads to the destruction of the membrane.

The value of the critical potential of breakdown can be determined from the expression (LEVYTSKA; MUSHYNSKYI; HUTSOL, 2017).

$$
\varphi_{K P}=\sqrt{0,376 E_{c+r} h^{2} / \varepsilon_{m} \varepsilon_{0}},
$$

where $E_{c+r}-$ is the module of elasticity of the membrane;

$h$ - is the thickness of the membrane;

$\varepsilon_{0}-$ is the electric constant.

According to the theory of electrical breakdown, an average lifetime of the membrane $(\bar{t}) \quad$ the EMF of SHF range can be represented by the expression

$$
\bar{t}=A e^{W / K_{b} \cdot T},
$$

where $A$ - is constant;

$W-$ is the maximum energy value of the membrane in terms of irradiation in it cylinder pores;

$K_{b}-$ is the Boltzmann constant.

To calculate the energy of the defect we should take into account the work connected with the change in the division surface, the membrane-solution due to the formation of the side cylinder surface and decrease division surface section with the 
help of section recession that corresponds to the cylinder sides (LEVYTSKA; MUSHYNSKYI; HUTSOL, 2017).

The dependence of the maximum meaning of $W$ energy defect on the critical potential value at the $\varphi_{\lim }$ membrane is determined by the expression:

$$
W=\frac{\pi \delta^{\Omega \%}}{\delta+C \frac{\varphi_{\lim }^{2}}{2}}
$$

The expressions (9) - (12) allow us to estimate the voltage magnitude of the EMF electrical component both in the cytoplasm of the microorganisms and membrane cytoplasm attuned frequency. However, the given expressions do not give the information about how optimal is a value of the electric voltage and what exhibition time of EMF action is required for decomposition of cell membranes of pathogenic cocci.

\subsection{Multiple calculations of biotropic EMF parameters for the oppression of pathogenic microorganisms}

The results of the study are considered to be the basis for previous determination of biotropic EMF parameters, which affect to oppress the pathogenic organisms in wounds of animal skin cover. In addition, these results will help to develop appropriate technical requirements for making electronic equipment.

As a result of the multiple calculations, the critical potential $\left(\varphi_{\text {lim }}\right)_{\text {for }}$ destruction of the plasmatic membrane of pathogenic cocci in wounds of animal skin should not be less than $110 \mathrm{mV}$. In case the potential is $110 \mathrm{mV}$ the membranes of pathogenic cocci, a critical radius of defect $\left(r_{0}\right)$ where transverse pore is not closed is 0,8 10-12 m (graph 5).

The shown correspondence proves (graph 5) the fact that the increase of the voltage potential at the membrane leads to a decreasing of the critical radius of pores and reducing the maximum importance of energy $(\mathrm{W})$.

The reduction of critical threshold power in terms of increasing the voltage potential by the external EMF leads to increasing the reliability of above-critical membrane defect. In case of such defect, membrane ruptures involuntarily because 
DOI: 10.14807/ijmp.v10i7.907

the increase of the size of the defect is accompanied by the decrease in free energy of the system.

This fact can explain the increasing probability of rupture in pathogenic microorganism membranes, which are influenced by EMF with optimal biotropic options.

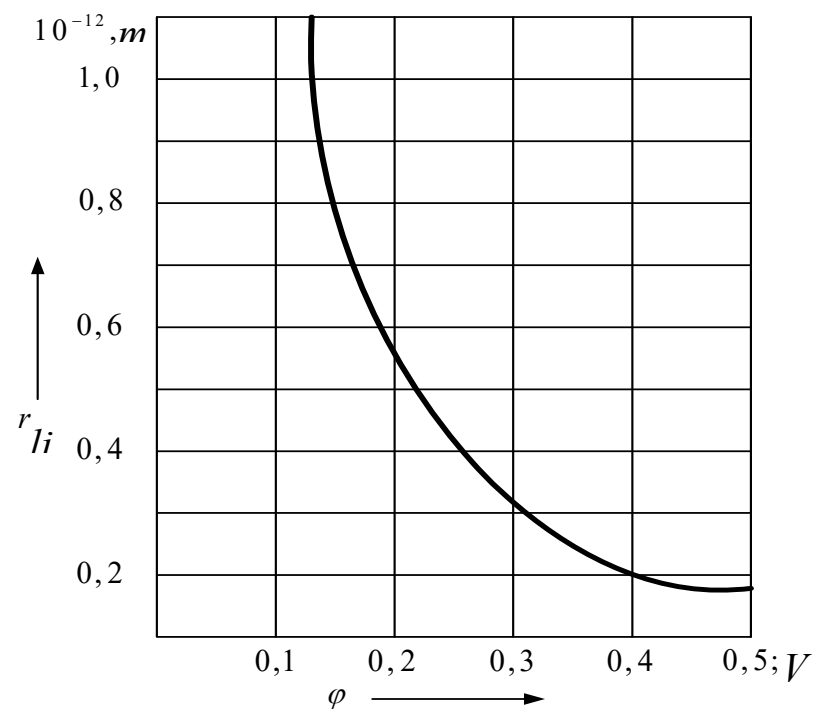

Graph 5: The dependence of the critical radius of transverse pores in the membranes of pathogenic cocci from the potential by external EMF

The increasing voltage potential on the membrane leads to decreasing in the critical radius of pores and reducing the maximum power (W) (graph 5).

Reduction of critical threshold power in terms of increasing the potential by the external EMF leads to increasing the reliability of above-critical defect of the membrane. Such defect causes the rupture of the membrane because the increasing size of the defect is accompanied by a decrease in the free energy of the system.

This explains the increasing probability of membrane rupture of pathogenic microorganisms, which are influenced by EMF with optimal biotropic options.

Graph 6 shows the dependence of the average lifetime of the membranes of pathogenic cocci on the difference of voltage potential on the membrane by the external EMF. 


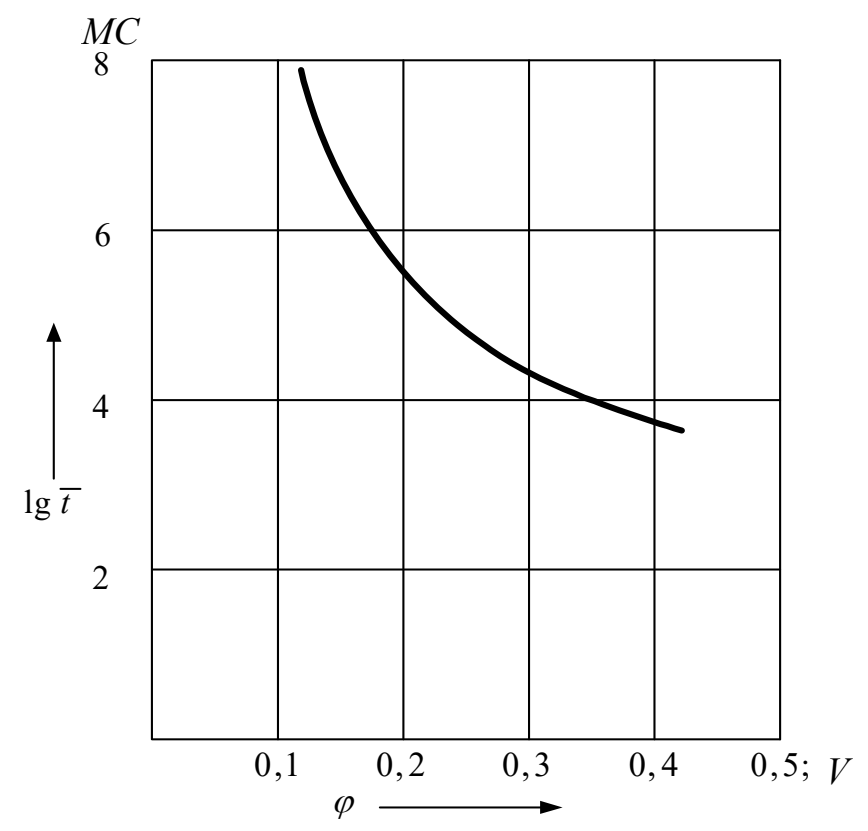

Graph 6: The dependence of the average lifetime of the pathogenic cocci membranes

The shown dependence (graph 6) proves the fact that the membrane lifetime, damaged by the cocci, influenced by external EMF, is cut in terms of the increasing difference. When the difference between voltage potential of more than $110 \mathrm{~V}$, the lifetime of the membrane of pathogenic cocci in wounds of animal skin cover amounts up to $1 \mathrm{~s}$.

\section{CONCLUSIONS}

The influence of high-frequency electromagnetic field of the radio-frequency voltage zone on the phase of animal skin cover will slow down the inflammation process, improving the blood circulation, microcirculation of blood and lymph, increasing the absorption of oxygen by tissues, activation of regenerative processes that will lead to a recovery of the animal.

The mechanism of interaction between the electromagnetic field and the microorganisms are studied with the help of theoretical exploration of distribution of these fields inside the cells of microorganisms. First of all, the scattering of a plane electromagnetic wave in biological objects that have the structure of the planeparallel layer of animal skin cover is concerned for the sake of simplicity: the first layer is a wool cover, the second one is skin, and the third one is the muscle.

To obtain the results, the calculations of electromagnetic fields inside the infected wounds of animal skin were done. In addition, the change of the electrical 
DOI: 10.14807/ijmp.v10i7.907

characteristics on the sides of the cylinder zone of field action is automatically taken into account by boundary conditions at the plane-parallel layers. The dependence of the amplitude of the electric field on the axis of the cylinder infected skin area on the frequency of incident electromagnetic field was examined in the study.

To conclude we should note that:

1) For the calculation of the EMF distribution in wounds of animal skin cover the expressions obtained for the plane-parallel environment should be used.

2) Oppression of pathogenic cocci in wounds of animal skin cover should be carried out with the use of EMF in the frequency range of $35-37 \mathrm{GHz}$ with a power density of not more than $5 \mathrm{mw} / \mathrm{cm}^{2}$ and an exhibition of $3-5 \mathrm{~min}$.

3) A lifetime of pathogenic cocci in wounds of animal skin cover influenced by the action of external EMF depends on the potential of the plasmatic cocci membrane, which critical value is $110 \mathrm{mw}$.

\section{REFERENCES}

AARON, R. K.; BOYAN, B. D.; CIOMBOR, D. M.; SCHWARTZ, Z.; SIMON, B. J. (2004) Stimulation of growth factor synthesis by electric and electromagnetic fields. Clinical Orthopaedics and Related Research (1976-2007), v. 419, p. 30-37.

BETSKII, O.; LEBEDEVA, N. (2004) Low-intensity millimeter waves in Biology and Medicine. Clinical application of Bioelectromagnetic Medicine. New-York, USA; Macel De-k Ker. Inc.

BECKIJ, O. V.; DEVYATKOV, N. D.; LEBEDEVA, N. N. (2000) Lechenie elektromagnitnymi polyami. Biomedicinskaya radioelektronika, n. 7, p. 3-9.

BORYSEVYCH, V. (1992) Zahalna veterynarna medytsyna [General Veterinary Surgery]. Kyiv: Vyshcha shkola.

CHERENKOV, A. D.; KOSULINA, N. G.; SAPRUCA, A. V. (November - December, 2015) Theoretical Analysis of Electromagnetic Field Electric Tension Distribution in the Seeds of Cereals. Research journal of Pharmaceutical, Biological and Chemical Sciences, v. 6, n. 6, p. 1686-1694.

CHERENKOV, A.; HUTSOL, T.; HARASYMCHUK, I.; PANTSYR, YU.; TERENOV, D.; DUBYNA, V. (2018) Analysis of broadband antenna radiation pulses.

Agricultural Engineering, Polskie towarzystwo inzynierii rolniczej, p.15-28.

CHURMASOV, A. V.; ZHUKOV, V. A.; KUKUSHKINA, D. M.; KALININA, A. V.; XIMINA, G. A. (1996) Vliyanie UF oblucheniya na produktivnost i povedenie.

Nizhegorodskij CNTI. Ser. R. 68.39.37, n. 49-96, P.4.

DZIEDZIC, K.; MUDRYK, K.; HUTSOL, T.; DZIEDZIC, B. (2018) Impact of grinding coconut shell and agglomeration pressure on quality parameters of briquette.

Engineering for rural development, p. 1884-1889. 
GOLANT, M. B. (1991) Rol millimetrovyx voln v processax zhiznedeyatelnosti. Mezhd. simp. Millimetrovye volny neteplovoj intensivnosti v medicine: Proceeding. Moskow: IRE AN SSSR. p. 545-547.

HUTSOL, T. (2017) Analysis of circuit solutions of radiometric receivers. Bulletin of the Kharkiv National Technical University of Agriculture Petro Vasilenko. Technical sciences, n. 187, p. 107-108.

HUTSOL, T. (2017) Research on suppression system analysis of high power narrowband interference operating in presence of heterodyne frequency. Scientific achievements in agricultural engineering, agronomy and veterinary medicine, v. 11, n. 1 , p. 264-273.

HUTSOL, T.; KOSULINA, N. (2016) Biofizicheskiye osnovy primeneniya radiometricheskikh priyemnikov dlya distantsionnoy diagnostiki sostoyaniya zhivotnykh. Zbirnyk naukovykh prats Podilskoho derzhavnoho ahrarnotekhnichnoho universytetu, v. 25, p. 73-79.

ILYIN, V. A.; POZNIAK, E. N. (1978) Lineynaya algebra [Linear algebra], Moskow: Nauka.

IVANYSHYN, V.; MISIUK, M.; ZAKHODYM, M.; HUTSOL, T. (2018) Methodological aspects of the research formation and regional market development of animal production. Scientific achievements in enviromental and life science. p. 29-40.

KALYNYCHENKO, A. V.; HORDYICHUK, Y. I. (2008) Vliyaniye potogennikh poley na membrannyy potentsial bakterialnoy kletki [EMF influence on membrane cell potential], Energosberezheniye. Energetika. Energoaudit.

Obshchegosudarstvennyy nauchno-proizvodstvennyy informatsionnyy zhurnal, n.1, p. 9-13.

KALYNYCHENKO, A. V.; HORDYICHUK, Y. I. (2006) Raspredeleniye vstroyennykh elektrokhimicheskikh poley $\mathrm{v}$ potogennikh kokhakh nakhodyashchikhsya pod vozdeystviyem vneshnego elektromagnitnogo izlucheniya [Distribution of external magnetic fields in pathogenic cocci], Energosberezheniye. Energetika.

Energoaudit. Obshchegosudarstvennyy nauchno-proizvodstvennyy informatsionnyy zhurnal, n. 11, p 31-36.

KALYNYCHENKO, A. V.; SEREDA, A. Y. (2007) Teoreticheskiy analiz po ugneteniyu infektsionnykh mikroorganizmov $v$ ranakh kozhnogo pokrova zhivotnikh nizkoenergeticheskim EMP KVCh diapazona [Theoretical analysis of infectious microorganism distribution in wounds of animal skin cover by low-energy electromagnetic field]. Vostochno-Evropeyskiy zhurnal peredovykh tekhnologiy, n. 6 , p. 123-129.

KALNYTSKYI, L. A.; DOBROTYN, D. A.; ZHVERZHYV, V. F. (1976) Spetsialnyy kurs vysshey matematiki [Advanced Mathematics]. Moscow: Vysshaya shkola.

KAMBOURIS, M. E.; ZAGORITI, Z.; LAGOUMINTZIS, G.; POULAS, K. (2014). From therapeutic electrotherapy to electroceuticals: formats, applications and prospects of electrostimulation. Annual Research \& Review in Biology, n. 4(20), p. 3054-3070.

KRASNOV, M. L.; KYSYLOV, N. Y.; MAKARENKO, N. Y. (1976) Integralnyye uravneniya [Integrated equation]. Moskow: Nauka.

LEVYTSKA, V.; MUSHYNSKYI, A.; HUTSOL, T. (2017) Detection and Diagnosis of Encephalitozoonosis in Rabbits under Ukraine-Specific Conditions. Scientific 
achievements in agricultural engineering, agronomy and veterinary medicine. TRAICON Publishing House. Krakow. p. 94-107.

LACY-HULBERT, A.; METCALFE, J. C.; HESKETH, R. (1998). Biological responses to electromagnetic fields. The FASEB Journal, v. 12, n. 6, p. 395-420.

ORLOV, B. N.; CHURMASOV, A. V.; KAZAKOV, A. V. (2000) Ekologofizologicheskie aspekty dejstviya nekogerentnyx elektromagnitnyx izluchenij na organizm Trudy Mezhd. konf. Eletromagnitnye izlucheniya v biologii. Kaluga, $p$. 135-139.

RUBYN, A. B. (1987) Biofizika: V 2-Kh kn.: Uchebnik dlya biol. Spets. Vuzov [Biophysics: workbook for biological specialties] Kn 2. Biofizika kletochnykh protsessov [Biophysics of cell process]. Moscow: Vyssh. Shkola.

SIMKÓ, M.; MATTSSON, M. O. (2004) Extremely low frequency electromagnetic fields as effectors of cellular responses in vitro: possible immune cell activation. Journal of cellular biochemistry, v. 93, n. 1, p. 83-92. 